\title{
PENGARUH SANITASI DI LINGKUNGAN TEMPAT TINGGAL TERHADAP KEJADIAN STUNTING PADA BALITA
}

(Studi di Wilayah Kerja Puskesmas Sumberjambe, Puskesmas Kasiyan dan Puskesmas Sumberbaru Kabupaten Jember Tahun 2018)

\author{
Ayik Nikmatul Laili* \\ *Program studi D III Kebidanan Fakultas Ilmu Kesehatan Universitas Bakti Indonesia Banyuwangi \\ email: aik.nikmah89@gmail.com
}

\begin{abstract}
ABSTRAK
Stunting merupakan gangguan pertumbuhan linier yang disebabkan oleh adanya malnutrisi asupan zat gizi maupun penyakit infeksi yang bersifat kronis. Jenis penelitian ini adalah observasional analitik dengan desain penelitian case control yang di wilayah kerja Puskesmas Sumberjambe, Kasiyan dan Sumberbaru pada bulan September-Oktober 2017. Sampel penelitian sebesar 71 responden kasus dan 71 responden kontrol. Responden dalam penelitian ini adalah ibu dari balita yang mengalami stunting dan tidak stunting dan bertempat tinggal di lokasi penelitian. Teknik sampling menggunakan cluster random sampling. Analisis data diolah menggunakan uji statistik regresi logistik tingkat signifikansi $\mathrm{p}$ $<0,05$. Hasil analisis data menunjukkan bahwa tidak terdapat pengaruh sanitasi lingkungan tempat tinggal terhadap kejadian stunting dengan nilai $p$-value $=1,000$. Sanitasi lingkungan di lokasi penelitian ini secara hampir secara keseluruhan mempunyai status buruk, baik sanitasi pada balita yang mengalami stunting maupun yang tidak stunting. Salah satu penyebab tidak adanya pengaruah yaitu dipengaruhi oleh faktor ketahanan pangan, kemungkinan anak dengan kondisi sanitasi lingkungan yang buruk mempunyai keluarga yang tahan pangan sehingga asupan nutrisi pada anak terpenuhi, hal ini yang menyebabkan anak tidak mengalami stunting. Saran yang dapat diberikan adalah diperlukannya kerjasama yang antar baik lintas sektoral dan masyarakat guna melakukan pengkajian ulang mengenai faktor penyebab lain dari kejadian stunting.
\end{abstract}

Kata Kunci: Stunting, sanitasi lingkungan

\begin{abstract}
Stunting is a linear growth disorder caused by malnutrition in nutrient intake and chronic infectious diseases. This type of research is observational analytic with case control research design in the working area of Sumberjambe, Kasiyan and Sumberbaru Health Centers in September-October 2017. The research sample is 71 case respondents and 71 control respondents. Respondents in this study were mothers of toddlers who were stunted and not stunted and resided at the study site. The sampling technique uses cluster random sampling. Data analysis was processed using a logistic regression statistical test of significance level $\mathrm{p}<0.05$. The results of the data analysis showed that there was no effect of environmental sanitation on the stunting event with a p-value $=1,000$. Environmental sanitation at this research site almost overall has a bad status, both sanitation among stunting and nonstunting toddlers. One of the causes of the lack of influence is that it is influenced by food security factors, the possibility of children with poor environmental sanitation conditions who have foodresistant families so that nutritional intake in children is met, this causes the child does not experience stunting. Suggestion that can be given is the need for cooperation between both sectors and the community to conduct a review of other factors causing stunting.
\end{abstract}

Keywords: Stunting, environmental sanitation 


\section{PENDAHULUAN}

Stunting merupakan gangguan pertumbuhan linier yang disebabkan oleh adanya malnutrisi asupan zat gizi maupun penyakit infeksi yang bersifat kronis. Kejadian tersebut terjadi secara berulang ditunjukkan dengan nilai Z-Score tinggi badan menurut usia (TB/U) kurang dari 2 standar deviasi (SD) berdasarkan standar WHO. Masalah stunting menjadi masalah gizi yang perlu mendapatkan perhatian karena dapat mempengaruhi kualitas sumber daya manusia.

Millenium Challenge Account Indonesia (2015) mengemukakan bahwa prevalensi stunting di Indonesia lebih tinggi daripada negara-negara lain di Asia tenggara, seperti Myanmar (35\%), Vietnam (23\%), dan Thailand (16\%). Di Indonesia, diperkirakan 7,8 juta anak usia di bawah 5 tahun mengalami stunting, data ini berdasarkan laporan yang dikeluarkan oleh UNICEF. Indonesia masuk dalam 5 besar negara dengan jumlah anak usia dibawah 5 tahun mengalami stunting yang tinggi. Prevalensi anak balita stunting di Indonesia berdasarkan hasil Riskesdas 2013 mencapai angka 37,2\% dan menduduki peringkat ke-24 dari 32 provinsi di Indonesia. Kejadian stunting pada Riskesdas tahun 2010 yaitu sebesar 35,6\% dan pada tahun 2007 yaitu sebesar $36,8 \%$. Prevalensi pendek sebesar 37,2 \% terdiri dari 18,0\% sangat pendek dan 19,2\% pendek. Tahun 2013 prevalensi sangat pendek menunjukkan adanya penurunan dari 18,8\% tahun 2007 dan 18,5\% tahun 2010, sedangkan untuk prevalensi pendek meningkat dari 18,0 $\%$ pada tahun 2007 menjadi 19,2\% pada tahun 2013.

Penyebab paling dasar dari tumbuh kembang bersumber dari masalah struktur politik, ideologi, dan sosial ekonomi yang dilandasi oleh potensi sumber daya yang ada. Penelitian yang dilakukan oleh Keino (2014) mengemukakan bahwa sosial ekonomi, demografi dan lingkungan merupakan faktor yang sangat berpengaruh secara signifikan terhadap determinan stunting pada anak. Faktor sosial ekonomi berkaitan dengan jenis pekerjaan dan pendapatan sehingga dapat mempengaruhi daya beli masyarakat. Faktor demografi dianggap penting karena karakteristik dari anak, orang tua, dan keluarga juga dapat berpengaruh terhadap pola asuh anak selain itu, lokasi tempat tinggal juga dapat menjadi faktor penentu, jika akses tempat tinggal dengan lokasi tempat untuk mendapatkan jenis makanan berjauhan akan semakin mempersulit untuk mendapatkan makanan. Faktor lain yang mempunyai pengaruh terhadap stunting yaitu lingkungan, dimana apabila lingkungan tempat tinggal anak tidak menerapkan perilaku hidup sehat, maka secara otomatis kondisi kesehatan anak akan terganggu termasuk masalah gizi dan stunting ini. Prevalensi balita stunting Tahun 2016 dari data Dinkes Kab. Jember, tertinggi berada di wilayah kerja Puskesmas Sumberjambe, Kasiyan dan Sumberbaru.

Masalah stunting terutama yang terjadi pada masa balita dianggap serius dikarenakan kondisi stunting pada masa balita dapat mengakibatkan keterlambatan perkembangan motorik dan menurunnya tingkat kecerdasan. Dampak lain yang timbul yaitu dapat menyebabkan depresi fungsi imunitas, perubahan metabolik, penurunan perkembangan motorik, menurunnya nilai kognitif dan nilai akademik. Anak yang mengalami stunting akan timbul dampak dalam jangka waktu yang panjang, diantaranya adalah beresiko obesitas, glucose tolerance, penyakit jantung koroner, hipertensi, osteoporosis, penurunan perfoma dan produktifitas (El-taguri et al, 2008).

Peneliti merasa perlu melakukan penelitian pengaruh sanitasi di lingkungan tempat tinggal terhadap kejadian stunting pada balita. Alasan dilakukan pada balita dikarenakan pada masa balita merupakan puncak masa pertumbuhan dan perkembangan sel dimana juka masalah kesehatan anak terganggu akan mempengaruhi proses pertumbuhan dan perkembangan tersebut. Penelitian ini akan dilakukan di tiga wilayah Puskesmas yang merupakan wilayah dengan kejadian stunting tertinggi pada Tahun 2016 yaitu di wilayah kerja Puskesmas Sumberjambe, Puskesmas Kasiyan dan Puskesmas Sumberbaru Kabupaten Jember.

\section{BAHAN DAN METODE}

Jenis penelitian ini adalah observasional analitik dengan desain penelitian case control. Penelitian ini dilakukan di wilayah kerja 
Puskesmas Sumberjambe, Kasiyan dan Sumberbaru pada bulan September-Oktober 2017. Sampel penelitian sebesar 71 responden kasus dan 71 responden kontrol. Responden dalam penelitian ini adalah ibu dari balita yang mengalami stunting dan tidak stunting dan bertempat tinggal di lokasi penelitian. Teknik sampling menggunakan cluster random sampling. Analisis data diolah menggunakan uji statistik regresi logistik tingkat signifikansi $\mathrm{p}<0,05$.

\section{HASIL}

Distribusi Kejadian Stunting Berdasarkan Kondisi Sanitasi Lingkungan Tempat Tinggal Balita dapat dilihat pada tabel 1.

Tabel 1 Distribusi Kejadian Stunting Berdasarkan Kondisi Sanitasi Lingkungan Tempat Tinggal Balita

\begin{tabular}{lcccccc}
\hline \multirow{3}{*}{ Sanitasi Lingkungan } & \multicolumn{3}{c}{ Kejadian Stunting } & \multicolumn{2}{c}{ Total } \\
\cline { 2 - 6 } & $\mathrm{n}$ & $\%$ & $\mathrm{n}$ & $\%$ & $\mathrm{~N}$ & $\%$ \\
\cline { 2 - 6 } & 71 & 50 & 71 & 50 & 142 & 100 \\
Tidak Sehat & 0 & 0 & 0 & 0 & & \\
Sehat & & & & & &
\end{tabular}

Hasil analisis data menunjukkan bahwa tidak ada pengaruh sanitasi lingkungan tempat tinggal terhadap kejadian stunting pada balita. Hasil distribusi data sanitasi lingkungan tidak dilakukan analisis, karena semua balita yang menderita stunting maupun tidak stunting mempunyai kondisi sanitasi lingkungan yang tidak sehat.

\section{PEMBAHASAN}

Hasil penelitian ini menunjukkan bahwa tidak terdapat pengaruh sanitasi lingkungan tempat tinggal terhadap kejadian stunting pada balita. Hasil analisis pada penelitian ini tidak sejalan dengan penelitian yang dilakukan oleh Renyoet, et.al (2013) yang menyatakan bahwa ada hubungan yang signifikan antara sanitasi lingkungan dengan kejadian stunting pada. Perbedaan ini diakibatkan oleh banyak faktor, faktor yang pertama adalah perbedaan lokasi penelitian. Lokasi penelitian pada tiap daerah terkadang menjadi perbedaan hasil penelitian, hal ini kemungkinan dipengaruhi oleh adanya perbedaan demografi dan budaya masyarakat. Sanitasi lingkungan di lokasi penelitian ini secara hampir secara keseluruhan mempunyai status buruk, baik sanitasi pada balita yang mengalami stunting maupun yang tidak stunting.

Hasil jawaban dari beberapa pertanyaan dari kuesioner tentang komponen rumah, sebagian besar kondisi rumah termasuk dalam kriteria rumah sehat. Rumah responden tergolong rumah baru dan mengikuti model rumah pada saat ini dengan kondisi tembok sudah permanen, terdapat langit-langit di dalam rumah, dan lantai rumah keramik dan bersih. Kondisi sarana sanitasi di wilayah Sumberjambe dan Sumber baru untuk sarana air bersihnya menggunakan air "pet" sebutan responden di wilayah tersebut. Air "pet" ini merupakan air tampungan yang bersumber dari gunung kemudian ditampung dan dialirkan ke penduduk sekitar. Kondisi air tersebut sangat jernih dan tidak berbau dan air tersebut digunakan untuk mandi dan memasak. Temuan lain pada saat pengambilan data khususnya di wilayah Sumberjambe dan Sumberbaru adalah hampir keseluruhan penduduk tidak memiliki jamban pribadi. Penduduk di daerah tersebut terbiasa buang air besar di sungai, selain itu sungai juga dipergunakan untuk mencuci baju, dan membuang limbah seperti contoh air bekas cucian baju maupun air bekas cucian peralatan memasak. Supariasa, et al (2012) dalam bukunya menuliskan bahwa penyakit diare, cacingan, dan infeksi saluran pencernaan disebabkan oleh sanitasi lingkungan yang kurang baik. Penyerapan zat-zat gizi akan terganggu pada anak yang seringkali menderita penyakit sakuran pencernaan, sehingga menyebabkan terjadinya kekurangan zat gizi. Seseorang dengan kekurangan zat gizi akan mudah terserang penyakit, dan petumbuhan akan terganggu.

Kondisi sarana sanitasi di wilayah Kasiyan, hampir keseluruhan responden mempunyai sumber mata air sendiri berupa sumur. Kondisi 
air dari sumur tersebut tidak jernih melainkan keruh seperti bercampur dengan tanah. Penduduk jika akan menggunakan air tersebut untuk memasak harus mendiamkan air tersebut selama minimal 1x24 jam sampai mengendap, baru kemudian air tersebut dapat digunakan. Temuan lain pada saat melakukan pengambilan data adalah di semua wilayah penelitian, hampir keseluruhan responden tidak memiliki sarana pembuangan limbah. Pembuangan limbah seperti sampah terkadang dibuang ke sungai, apalagi pada saat musim penghujan. Beberapa responden mengatakan bahwa mereka tidak memiliki lahan untuk membuat lubang sampah di sekitar rumahnya. Gibney, et al (2009) berpendapat bahwa ketersediaan air yang aman, penyiapan makanan yang bersih, dan pembuangan limbah yang tepat merupakan unsur-unsur esensial dalam mencegah tubuh yang pendek ataupun gizi kurang yang kronis, namun keadaan tersebut tidak akan terwujud apabila penduduk dalam kondisi kemiskinan yang ekstern.

Kondisi lingkungan hasil temuan penelitian sebagaimana sudah dijelaskan, ternyata tidak mempunyai pengaruh terhadap kejadian stunting di wilayah tersebut. Penyebabnya kemungkinan besar dipengaruhi oleh faktor lain, contohnya balita yang normal atau tidak mengalami stunting mempunyai sanitasi lingkungan yang buruk akan tetapi orang tua menerapkan pola asuh yang baik kepada anak sehingga menyebabkan anak tidak stunting. Penyebab yang lainnya yaitu ketahanan pangan, kemungkinan anak dengan kondisi sanitasi lingkungan yang buruk mempunyai keluarga yang tahan pangan sehingga asupan nutrisi pada anak terpenuhi, hal ini yang menyebabkan anak tidak mengalami stunting.

\section{SIMPULAN DAN SARAN}

\section{Simpulan}

Sanitasi lingkungan yang baik maupun buruk tidak akan meningkatkan risiko kejadian stunting pada balita.

\section{Saran}

Saran yang dapat diberikan kepada Dinas terkait adalah sosialisasi tentang screening kejadian stunting terutama pada balita guna mencegah kejadian stunting guna mencari penyebab lain yang berpotensi mengakibatkan kejadian stunting. Selain itu perlu dilakukan kajian ilmiah yang lain untuk mencari dan membahas penyebab lain dari kejadian stunting yang utamanya terjadi pada balita.

\section{KEPUSTAKAAN}

Arikunto. 2010. Prosedur Penelitian Suatu Pendekatan Praktis. Jakarta : Penerbit Rineka Cipta.

Dinas Kesehatan Kabupaten Jember. 2015. Data Hasil PSG. Jember: Dinas Kesehatan Kabupaten Jember.

El-Taguri, A., Ibrahim, B., Salah, M. M., dan Abdel, M. A. 2008. Risk Factors for Stunting Among Under-fives in Libya. Jurnal: Public Health Nutrition, 12(8):1141-1149.

Erdhat, J. 2007. Nutrisurvey for Windows. Copyright (C). Seameo-Tropined RRCNUniversity of Indonesia. Hidayat, A. A. 2008. Buku Saku Praktikum Keperawatan Anak. Jakarta: EGC

Hidayat, M. dan Hidayat, A. A. 2008. Keterampilan Dasar Praktik Klinik Untuk Kebidanan. Jakarta: Salemba Medika.

Hidayat, M. dan Hidayat, A. A. 2008. Pengantar Ilmu Kesehatan Anak untuk Pendidikan Kebidanan. Jakarta: Salemba Medika.

Keino, S., Guy, P., Grace, E., dan Bart van den, B. 2014. Determinants of stunting and overweight among young children and adolescents in sub-Saharan Africa.

Food Nutritions Jurnal Pubmed: 35(2):167-78.

Kementrian Kesehatan RI. 2010. Laporan Hasil Riset Kesehtan Dasar (Riskesdas) Tahun 2010. Jakarta: Kementrian Kesehatan RI. Kementrian Kesehatan RI. 2013.

Laporan Hasil Riset Kesehtan Dasar (Riskesdas) Tahun 2013. Jakarta: Kementrian Kesehatan RI. Lestari, W., Margawati, A., dan Rahfiludin, M. 2014. Faktor Risiko Stunting pada Anak Umur 6-24 Bulan di Kecamatan Penanggalan Kota Subussalam Provinsi Aceh. Jurnal Gizi Indonesia, 3(1), 37-45. http://ejournal. undip.ac.id/index.php/jgi/article/downl 
oad/8752/7081. [Diakses pada 1 Desember 2017].

Lutviana, E. dan Budiono, I. 2010. Prevalensi dan Determinan Kejadian Gizi Kurang pada Balita. ISSN: 1858-1196

Masibo, P.K., dan Makhoha, D. 2012. Trends and determinants of undernutrition among young Kenyan children: Kenya Demographic and Health Survey; 1993, 1998, 2003 and 2008-2009. Public Health Nutrition: 15(9):1715-27.

Nazir, M. 2009. Metode Penelitian. Bogor : Ghalia Indonesia.

Notoatmodjo, S. 2012. Metode Penelitian Kesehatan. Jakarta : Rineka Cipta.

Oktarina, Z. dan Trini, S. 2013. Faktor Risiko Stunting pada Balita (24-59 bulan) di Sumatra. Jurnal Gizi dan Pangan: 8 (3): 175-180. ISSN 1978-1059.

Pahlevi, A. E. 2012. Determinan Status Gizi pada Siswa Sekolah Dasar. ISSN: 11961858

Ronyoet, B. S., Venie, H. dan Siti, N. R. 2013. Hubungan Pola Asuh dengan Kejadian Stunting pada Anak Usia 6-23 Bulan di Wilayah Pesisir Kecamatan Tallo Kota Makassar. Skripsi: Program Studi Ilmu Gizi Fakultas Ilmu Kesehatan Masyarakat Universitas Hasanuddin Makasar.
Rosha, B. C., Hardiansyah dan Baliwati, Y. F. 2012. Analisis Determinan Stunting pada Anak 0-23 Bulan pada Daerah Miskin di Jawa Tengah dan Jawa Timur. Panel Gizi Makanan, 35(1): 34-41.

Sulastri, D. 2012. Faktor Determinan Kejadian Stunting pada Anak Usia Sekolah di Kecamatan Lubuk Kilangan Kota Padang. Majalah Kedokteran Andalas No.1. Vol.36. Padang: Bagian Ilmu Gizi Fakultas Kedokteran Universitas Andalas.

Teshome. B.,Wambui, K. G., Zewditu, G., dan Girum, T. 2011. Magnitude and determinants of stunting in children underfive years of age in food surplus region of Ethiopia: The case of West Gojam Zone. Ethiopia Journal of Health Development: 23(2): 98-106.

WHO. 2010. Nutrition Landscape Information System (NLIS) Country Profile Indicators: Interpretation Guide. Switzerland: WHO Press. 